\title{
A research on the Sports Tourism Special Project In Hainan International Tourism Island
}

\author{
Xia Minhui WangHui Wang Xiaolin SuYou \\ (School of Physical Education, Hainan Normal University, Haikou, Hainan, China 571158)
}

\begin{abstract}
At the background of the constrictions of international tourist island, this paper applies the methods of literature review, the interview, in-site investigation to analyze the current development of the sports tourism in Hainan with a benchmark of the construction plan of the Hainan international tourist island and the combination of the world's four famous tourism Islanders. It makes a planning assumption of the development of the sports tourism in accordance with the characteristics of sports tourism resources in Hainan. The tourism resources in Hainan are rich and unique. It aims to set up the development planning guidelines and objectives of sports tourism in Hainan, to clarify the spatial layout of resources, the distribution of different sports tourism zones and the tourism routes, to propose the project plans of the sports tourism in Hainan with a combination of the construction of international tourism island, to establish a sports tourism industry in cooperation with large enterprises in a new concept of society development.

The sports tourism development project makes a combination among the tourism products, tourism program and tourist routes. It strengthens the cooperation in different bureaus in the sports and tourism management, to accelerate the construction and sport tourism personnel training, to standardized the management, other safeguards and construct the camp for self-driving tourists, the motel , the auto theater and launch the Hainan Card to increase the "migratory birds" economic and promote the development of the tourism in Xisha Island, Nansha Island.
\end{abstract}

Keywords: Hainan; International Tourism Island; Sports tourism; Special project

\section{Introduction}

As a kind of phenomenon of dominant economic, the tourism industry displays strong momentum in Hainan economy in recent years and has shown great influence and potential in the development. During the" Twelve -five "project, the tourism plays an important role in the economy of our country with a sign that China enters a period of rapid economy growth. The sports tourism will become the important content of ordinary people, as it is a combination of the material civilization, the spiritual civilization and ecological civilization.

In twenty-first Century, good health and leisure activities are one of hot pursuit for ordinary people, and sports are one of the health activities people advocate. It is suggested to merge the sports and tourism as a new industrial mode at the background of the construction of Hainan international tourism island. It will bring more considerable economic benefits and social benefits to the construction of Hainan international tourism island in the near future, guide and inspire people to set up positive attitude and healthy, civilized way of life. Therefore, the sports tourism plays an important role in the construction of international tourism island.

The development plan for the construction of Hainan international tourism island was put forward by Hainan provincial Party committee and Hainan provincial government in June, 2010. With the methods of literature review, the interview, on-the-spot investigation, this research proposes on the development projects of the sports tourism in Hainan are as follows:

\section{The Results And The Analysis}

A The analysis of current development of sports tourism in Hainan with the combination of the four largest tourist islands in the world

At present, many famous tourist island resort spread out the world, such as the well-known Hawaii in the United States, Jeju Island of South Korea, Bali Island in Indonesia and Phuket Island in Thailand. From Table 1 The comparative analysis between Hainan Island and the world's four largest tourist island, it is true that Hainan Island is not inferior at the geographical location, the climate, the natural scenery and the human culture to the four famous tourist islands. But its international reputation is far beyond the four famous tourist islands, which shows that the development of Hainan is late and its propaganda efforts were not enough.

In the opportunity of the international tourism island, it is urgent to discover the unique characteristics in Hainan on the focus of the project in Hainan tourism. Hainan Island won't attract the foreign tourists only by the sunshine, the beach and the delicious food, comparing with the four famous island resorts. The government should develop an attraction with local characteristics of tourism recognized by the international tourists. And the related industries of sports and tourism, the integration and development of sports tourism will become new resources in the international tourism island.

A task of A research on the Sports Tourism Special Project In Hainan International Tourism Island, the key research project in The State General Administration of sport social science, number: 1461SS10015, The Second Chinese Postdoctoral Sports Forum Report An introduction to the author: Xia Minhui ( 1963 ), female, Zigong, Sichuan, Dean of school of P.E., Hainan Normal University, Professor, doctor, supervisor of masters, research filed: sports humanistic sociology. The Corresponding author: Wang Hui, School of P.E., Hainan Normal University, research filed: sports humanistic sociology. 
Table 1 The comparative analysis between Hainan Island and the world's four largest tourist island

\begin{tabular}{|c|c|c|c|c|c|}
\hline & Bali Island & Hawaii & huket Island & Jeju Island & Hainan Island \\
\hline $\begin{array}{l}\text { The } \\
\text { location }\end{array}$ & $\begin{array}{l}\text { Indonesia' s most } \\
\text { dazzling Island, } \\
\text { located in } 8 \\
\text { degrees of the } \\
\text { equator of Indian } \\
\text { ocean, East Java }\end{array}$ & $\begin{array}{l}\text { Located in the } \\
\text { central } \\
\text { Pacific, the } \\
\text { largest island } \\
\text { in the Hawaii } \\
\text { islands, } \\
\text { warm }\end{array}$ & $\begin{array}{l}\text { A city of southern } \\
\text { Thailand and the } \\
\text { island, located } \\
\text { off the west coast } \\
\text { of the Malay } \\
\text { Peninsula of } \\
\text { Dammam, warm }\end{array}$ & $\begin{array}{l}\text { Located in the East } \\
\text { China Sea, in the } \\
\text { southwest area of } \\
\text { the Korean } \\
\text { Peninsula, the } \\
\text { biggest South } \\
\text { Korean island }\end{array}$ & $\begin{array}{l}\text { Hainan Island is } \\
\text { located in the } \\
\text { southern part of the } \\
\text { Leizhou peninsula in } \\
\text { our, north across the } \\
\text { Qiongzhou Strait, the } \\
\text { second largest island } \\
\text { in China. }\end{array}$ \\
\hline $\begin{array}{l}\text { The } \\
\text { Climate }\end{array}$ & $\begin{array}{l}\text { tropical island, } \\
\text { hot, the annual } \\
\text { average } \\
\text { temperature is } \\
\text { about } 28 \text { degrees }\end{array}$ & $\begin{array}{l}\text { in the } \\
\text { tropical } \\
\text { mild and } \\
\text { pleasant, }\end{array}$ & $\begin{array}{l}\text { in the tropics, } \\
\text { humid }\end{array}$ & $\begin{array}{l}\text { temperate maritime } \\
\text { climate of the } \\
\text { annual average } \\
\text { temperature of } 14.7 \\
\text { degrees Celsius, } \\
\text { winter } 4.7 \mathrm{C}\end{array}$ & $\begin{array}{l}\text { The maritime tropical } \\
\text { monsoon climate, the } \\
\text { average annual } \\
\text { temperature between } \\
22 \text { degrees and } 26 \\
\text { degrees }\end{array}$ \\
\hline $\begin{array}{l}\text { Natural } \\
\text { scenery }\end{array}$ & $\begin{array}{l}\text { "The navel of the } \\
\text { world" Mount } \\
\text { Agung, national } \\
\text { forest, the } \\
\text { largest lake, } \\
\text { beautiful beaches }\end{array}$ & $\begin{array}{l}\text { Honolulu, } \\
\text { Wilkie beach } \\
\text { and Pearl } \\
\text { Harbor, } \\
\text { Volcano Island }\end{array}$ & $\begin{array}{l}\text { the beach, the odd } \\
\text { shape lime rock } \\
\text { and the jungle }\end{array}$ & $\begin{array}{l}\text { Three treasure, } \\
\text { Jeju island volcano } \\
\text { and lava tubes, } \\
\text { bonsai garden, } \\
\text { Halla etc. }\end{array}$ & $\begin{array}{l}\text { Majestic volcano } \\
\text { scenery, mangrove, } \\
\text { Yalong Bay, Monkey } \\
\text { Island, Coconut } \\
\text { Grove, the remotest } \\
\text { corners of the globe }\end{array}$ \\
\hline $\begin{array}{l}\text { Human } \\
\text { Culture }\end{array}$ & $\begin{array}{l}\text { A strong religious } \\
\text { culture, almost } \\
\text { all culture } \\
\text { related religion, } \\
\text { such as music, } \\
\text { sculpture, shadow } \\
\text { plays and so on }\end{array}$ & $\begin{array}{l}\text { Polynesian } \\
\text { culture, and a } \\
\text { unique } \\
\text { cultural } \\
\text { performances } \\
\text { such as Hula }\end{array}$ & $\begin{array}{l}\text { the rich Buddhist } \\
\text { culture, carnival } \\
\text { from November, } \\
\text { Seafood Festival }\end{array}$ & $\begin{array}{l}\text { Jeju folk } \\
\text { performances, such } \\
\text { as the female } \\
\text { dance, the famous } \\
\text { Yeongju sites }\end{array}$ & $\begin{array}{l}\text { a strong culture of } \\
\text { minority } \\
\text { nationalities with } \\
\text { Li, Miao, Hui minority } \\
\text { residents }\end{array}$ \\
\hline $\begin{array}{l}\text { Reputati } \\
\text { on }\end{array}$ & $\begin{array}{l}\text { Flower island, } \\
\text { South Park, Fairy } \\
\text { Island, Island of } \\
\text { thousands of } \\
\text { Temples }\end{array}$ & Pacific pearl & Thai Pearl & $\begin{array}{l}\text { South } \\
\text { Hawaii, the } \\
\text { honeymoon island, } \\
\text { romantic island }\end{array}$ & $\begin{array}{l}\text { The eastern Hawaii and } \\
\text { the pearl of the } \\
\text { Chinese southern sea }\end{array}$ \\
\hline
\end{tabular}

According to Song Jingmin's [2 ], (2010) research, sports tourism resources in Hainan can be divided into two major parts: the natural and the humanities.

The natural tropical sports tourism resources include four subclasses: the sea, the mountain, the water, and the ecological. The humanistic sports tourism resources also include four subclasses: the folk, the festivals, the events and the venues base. Sports tourism resources in Hainan include 512 kinds of programs; therefore, Hainan Island sports tourism resources are rich, unique, and indeed superior to the world's four famous islands.

$B$ The guided theory and target of the sports tourism project

\section{1) The guided theory}

With the guide of the scientific development and the twelve five planning of Hainan national economy and social development, the help of the development project of the construction of Hainan international tourism island, The provincial government makes the development strategy to speed up the tourism industry, the planning principle to promote the tourism and sports, tourism industry chain, the goals of development in the sports tourism products and cultivation of the International tourism brand, the leading roles of the sports tourism. The government constructs Hainan Island as the international, the first-class Asian sports tourism destination [3 ].

The goals of three stages:

The goal in the near future (2010-2013) -

From 2010 to 2013, Hainan Government will improve infrastructure construction of Hainan sports tourism and initially establish the image of the characteristics of sports tourism. With the full implementation of the " one mountain, two islands, two bays, two drift, a culture, two base" and " the sea, the mountain, the hill, the spring" sports tourism model, the benefit of sports tourism economic will begin to rise and make Hainan a unique island for sports tourism.

The metaphase target (2014 - 2017 ) 
An aim to build large-scale comprehensive sports facilities in Hainan and hold large and medium-sized domestic and international sporting events, the government will perfect the sports tourism industry system to influent "bead trigonometry" and "extensive bead triangle" area sports tourism market. The sports tourism economic implementation grows rapidly, so that the sports tourism in Hainan will become the dominant one to lay the foundation for Hainan to become a tropical sports tourism vocational resort.

The long term goals ( 2018-2020)

By the formation and perfection of the sports tourism industry system and 20 types of sports tourism, the completion of the sports tourism and regional economic optimization, it will preliminary built Hainan into the first-class, world famous tropical tourism destination.

$C$ The development project of the main field of sports tourism

The project of Hainan sports tourism mainly integrates with the sports tourism products, tourism program, the tourist routes. This research implements the 756 project at the National Space base with the layout of sports tourism and the different partition of recreational sports.
1) The implementation of the "756 project"
" 7": The seven zones and seven CentersSeven sports tourism zone:

(1) The diving sports tourism zone in Chinese southern sea:

The west Island $\rightarrow$ Yalong Bay $\rightarrow$ Dadong $\quad \mathrm{Sea} \rightarrow$ Wuzhizhou Island

(2) The exploration of folk sports tourism zone in central Hainan:

Five Fingers Mountain mountaineering $\rightarrow$ drifting in the Five Fingers Mountain $\rightarrow$ exploring of folk culture the Five Fingers Mountain $\rightarrow$ the Rainforest Adventure

(3) The leisure sports tourism zone in the eastern part:

The Wanquan River upstream exploration $\rightarrow$ drifting of Wanquan River downstream area $\rightarrow$ Boao Golf $\rightarrow$ Boao Hot Spring

(4) The southwest tropical rain forest or wilderness adventure sports tourism zone

The adventure of tropical rain forest in DiaoLuo mountain $\rightarrow$ a view of the DiaoLuo mountain fall $\rightarrow$ Jianfeng Mount mountaineering $\rightarrow$ Seven Fairy Mount mountaineering, the rock climbing $\rightarrow$ the spa

( 5) The recovery sports tourism zone in the southeast: Enjoy Xinglong hot springs $\rightarrow$ tour the forest park $\rightarrow$ play golf $\rightarrow$ tour the tropical botanical garden $\rightarrow$ tour the garden of Southeast Asian $\rightarrow$ Dongshan Mount mountaineering

(6) The northern suburbs of Haikou sports tourism zone:

The western Beach $\rightarrow$ The holidays beach $\rightarrow$ The roller skating leisure gallery $\rightarrow$ the sailing training base $\rightarrow$ watch the impression of Hainan show

(7) The northeast mountain sports tourism zone:
Tongguling mountaineering $\rightarrow$ tour $\quad$ Moon Bay $\rightarrow$ the White Gold Coast Beach Sports $\rightarrow$

Gao Long Bay National beach volleyball training base $\rightarrow$ visit the space launch base

Seven sports tourism service center: Haikou, Sanya, Qionghai, Wenchang, Five Fingers Mountain County, Baoting, Xinglong.

The " 5": Five sports tourism themes and five sports tourism focus

Five sports tourism theme: fitness and leisure sports tourism, the adventure sports tourism, the sports events tourism, the festivals sports tourism, the folk culture sports tourism.

Five major sports tourism zone:

(1) the Dadong Sea, Yalong Bay, West sea sports tourism zone

(2) Five Fingers mountain, rafting, adventure sports and folk culture tourism zone

(3)Seven Fairy Mount Mountaineering, rock climbing, hot springs Sports Tourism Zone

(4) hot spring in Xinglong, the Southeast Asian garden, the forest oxygen bar Sports Tourism Zone

(5) Tongguling Mount, Gao Long Bay, Qinglan harbor Marine Leisure Sports Tourism Zone

" 6": Six sports tourism products and six sports tourism system

The six sports tourism products: golf leisure travel, tropical seaside spa tour, folk customs tour, Li Miao boutique tour, sports event tour, the Diving tour in South China Sea, the tropical Valley rafting tour.

Six sports tourism system: a comprehensive sports tourism service system; innovative features sports tourism product system; strict implementation of quality assurance system; normative and orderly operation of the market system; the convenience and flexibility of the information and marketing system; people-oriented management system.

2) The map of the spatial distribution of development of sports tourism project (Figure 1)

3) Sports tourism routes

According to the distribution of Hainan sports tourism resource, the transportation and industry, Hainan sports tourism routes may be developed in the following combinations routes:

Coastal sports tourism routes:

The southern line: Yalong Bay $\rightarrow$ Dadong Sea $\rightarrow$ beach sports and diving of the west island, marine sports line.

The Eastern Line: Tongguling mountaineering $\rightarrow$ swimming in the sea $\rightarrow$ beach base $\rightarrow$ Gao Long bay beach volleyball base line.

The Sports tourism routes in the forest:

(1) The Diao Luo Mount national Forest Park $\rightarrow$ Baihualing falls $\rightarrow$ Seven Fairy Mount spa $\rightarrow$ a tropical rain forest adventure $\rightarrow$ Sports tourism in the wild

(2) Adventure in tropical rain forest of Bawang Mount $\rightarrow$ Adventure in Tropical Rainforest of Jianfengling $\rightarrow$ Mao Gongshan Nature Reserve

2.3.3.3 The hot springs sports tourism routes: 
(1) Guantanghot springs in the southeast $\rightarrow$ hot spring in Xinglong $\rightarrow$ Tropical Botanical Garden $\rightarrow$ Hot Spring in Nantian

(2) Danzhou Lanyang Hot Springs $\rightarrow$ Songtao lake $\rightarrow$ Changjiang Qizi Bay natural landscape

2.3.3.4 The adventure sports tourism routes

(1) Climbing Five Figure Mount $\rightarrow$ the drifting $\rightarrow$ the tropical rainforest $\rightarrow$ folk sports tourism in folk culture $\rightarrow$ adventure sports tourism lines.

(2) The drifting in Wanquan River $\rightarrow$ Boao Golf and $\rightarrow$ auto test base $\rightarrow$ Boao hot spring tourism line.

The sports tourism routes in the suburban

The sports tourism tour in the suburban of Haikou: swimming in West Coast, skating, sailing, windsurfing, marine sports, hot springs spa, mountaineering in the volcano park

The sports tourism tour in the suburban of Wenchang: Mangrove Nature Reserve, the civilized eco-village tour, space launch base tour, the coconut tree climbing contest, the experience of 9 people volleyball match in Hainan.

\section{The Development Strategy of the Sports Tourism}

A The match between the sports tourism planning and the construction of international tourism island

It is in need to understand the development of sports tourism, to establish a new concept of the development of sports tourism industry, market, product, to introduce the regional sports tourism resources as a whole tourism products to market, to discover the cultural connotation in sports tourism, to optimize the environment of regional sports tourism, to integrate the sports tourism products, to improve the sports tourism image and its industry system, to achieve the harmonious social, economic and cultural development between the sports tourism in the urban and rural.

$B$ Making uses of the leading role of the government and having a Hainan characteristic sport tourism

Hainan government implements the dominant development strategy of sports tourism, plans the development of sports tourism in a sound way. In order to ensure that the Hainan sports tourism is in accordance with the right direction of development, the accurate development policy, reasonable resource integration, scientific layout of resources and the rational of planning and management, it should combine the national fitness and the recreation together. The plans show the prominent characteristic of tropical island sports tourism and promote the further development of sports tourism in Hainan.

C Strengthening the cooperation between the Sports Departments and The Tourism Departments, advertising and promoting the development of the international tourism island

The Sports tourism is the combination of sports and tourism, a new form of generating the features between the tourism and the sports. Its development must depend on the integration of the two industries. Strengthening the cooperation between the Sports Departments and The Tourism Departments, these two departments need the management and the coordination the provincial Party committee, especially solve the problem of assigning the specific work of each part and the distribution of profit, to advertise and promote development of the international tourism island

$D$ The acceleration of the process of infrastructure of the international sports tourism

To accelerate the infrastructure of the sports tourism, the Sports Tourism Bureau cooperates with the large enterprises to create a good atmosphere of development.With the construction of Hainan National Park Planning, we hope that the development of sports tourism and the sports facilities may be included in the planning and construction of International Island at the same time

E Accelerating the sports tour personnel training and solving the shortage of talents

With the rapid development of sports tourism, the lack of the sports tourism professionals is a big problem. At present, the sports tourism professionals are hardly found in the sport tourism market, most of them are laypersons. Few professionals are engaged in the management and training work of sports tourism, which seriously restricting development of the sports tourism. With the construction of the international tourism island, an increase in demand for talented people is in need, it is suggested the government help the provincial universities to establish the related majors, in order to speed up the training of sports tourism professionals.

F Strengthening the standard management and carrying out the active the industrial orientated

Sports tourism is a special form of tourism, which means many special equipment conditions must be satisfied. It must go through a strict examination and approval because it is related to the safety of the tourists. With the guarantee of the safety, the sports tourism must meet four conditions including the resources, the facilities, the services and the insurance, most important of all, the standard and professional management team. It is necessary to create an active sport tourism industry chain in order to promote the development of related industries.

\section{Suggestions}

A Strengthening the Building of International Camping Facilities such as Auto camps and Motels

International Camping sites are important package facilities needed for the building of Hainan International Tourism Island. Tourists on the drive are to be accommodated at auto camps, the provision of which is based on the flow of sport tourists. Auto camps and motels of different sizes should also be established in the East, Central and the West express way areas.

B Developing "Recreation Vehicles" with Hainan Characteristics

With the rapid development of Self-drive tourism, Recreation Vehicle (RV) has caught the attention of RV 
manufacturers from home and broad, RV clubs and camping lovers. RV travel becomes popular among a growing number of tourists and has attracted more business investments. Given the huge market potential of RV in our country, we should make a vigorous effort to develop RVs with distinctive Hainan characteristics as soon as possible.

\section{C “Auto Cinema", Place to experience a fashionable} cultural life.

Auto cinema offers tourists a fascinating way of entertainment that enables them to see a movie in the open while sitting in their cars with an easy tune for audio streams. Needless to say, it has become a venue for romantic gathering among families and friends. Going forward, we should consider the prospect of building auto cinemas on the west coast of Haikou as well as in Sanya to keep up with the increasing number of self-drive camps and motels, taking full advantage of the island's soothing natural environment and broad coastlines.

D Developing "Marine Sports" and "Marine Festivals"

Known as "Pearl of the South China Sea", Hainan is blessed with a favorable geographical location, a mild climate and bountiful tourism resources. Activities related to the ocean, diving and the beach are distinctive local features. Located on the west coast of Haikou, the National Offshore Yachting and Boardsailing Base is also the venue for the Yachting and Boardsailing preliminary race in the 10th National Games. It is prospective that the area be built into a marine sport center that accommodates tourists as well as those who come to spend their leisure time and holidays. Moreover, the introduction of "Diving Festival", "Ocean Festival", "Beach Festival" and "Water Festival" will add to the unique charm of the tropical island.

E Revitalize Hainan as Winter Training Base for National Sports

The favorable natural environment and climate conditions makes it possible to maintain the supply of fresh fruits and vegetables all year round in Hainan, which has laid a solid foundation for a growing winter training industry. Yet the past years have seen the shut-down of some training bases due to the lack of infrastructure and facilities that suits high-level sport training. Athletes are a high consumption group that has much to contribute to the local economy. An athlete who stays for a 3-month training period consumes as much as 1,000 tourists combined. This special group brings enormous economic and social benefits to Hainan. Therefore, relevant administrative departments should attach more importance to the building of these winter training bases.

F Seek to Develop Advanced Sports Economy and Emphasize the Role of "Migratory birds"

"Migratory birds" here refers to a medium and long-term group of tourists who play a significant role in Hainan's economic development in its effort to become an international tourism island. Going forward, a number of internationalized, high-standard nursing homes will be built for the elderly, where health and nursing services will be provided. Meanwhile, efforts will be made to promote Tai-Chi, dances and variant sports activities for senior citizens to ensure they have a comfortable and healthy stay and at the same time encourage them to provide intellectual support for the scientific development of Hainan.

$H$ Developing a Convenient Electronic Financial system for Tourists- "Hainan Card"

Known as one of the earliest and the most successful electronic currencies in the world, Hong Kong's Octopus card is immensely popular among tourists for its convenience to pay and flexibility to recharge. The card is widely accepted in public transportation, stores, restaurants, parking lots and etc. One may even use it as an access card to schools, offices and houses. The purpose to build an international tourism island is to serve tourists from both home and abroad and the people of Hainan. Apart from developing hardware facilities, the financial sector in Hainan should consider the viability of a "Hainan card" to make life more convenient for residents on the island as well as for the tourists. We may even consider the prospect of interworking with Octopus.

G Making Xisha and Nasha Travel Available to Tourists

In its bid to develop itself into an International Tourism island, Hainan should seek more policy support from the central government to make it available for tourists to travel to Xisha, Nansha and other South China Sea islands within China's jurisdiction. By doing so, Hainan will be able to live up to the responsibility of defending and developing the South China Sea area, serve the need of building an International Tourism Island as well as the need to safeguard national sovereignty.

\section{REFERENCES}

[1] Pang Yan,The research into the development of Hainan sports tourism based on the context of international tourism island of, National strategy: the construction of Hainan international tourism island [M ], Haikou, the Nanhai press 2010.1, ( 329-335)

[2] Song Jingmin, A research on the tropical Hainan sports tourism resources investigation and development strategy, National strategy: the construction of Hainan international tourism island [M ], Haikou, the Nanhai press 2010.1, (300-314)

[3] Xia Minhui, The development of sports tourism in Hainan [M ], Beijing, Beijing Sports University press, 2005, (168-169), (178-182)

[4] Xia Minhui,The sports tourism industry from the perspective of international tourism island, National strategy: the construction of Hainan international tourism island [ $\mathrm{M}$ ], 2010.1, ( 291-299)

[5]1 Standeven, J., \& De Knop, P. Sport Tourism. Champaign, IL: Human Kinetics. c1999

[6] Thomas Hinch.al, Sport Tourism Development[M], Clevedon; Buffalo Channel View Publications, c2004 